\title{
PENGEMBANGAN SISTEM TEMU KEMBALI INFORMASI YURISPRUDENSI BERBASIS CONTENT MANAGEMENT SYSTEM (STUDI KASUS PERPUSTAKAAN HUKUM DANIEL S. LEV)
}

\author{
Fateh Hibatulwafi ${ }^{1}$ dan Wardiyono ${ }^{2}$ \\ ${ }^{1}$ Aksaramaya, Jakarta \\ ${ }^{2}$ Program Studi Perpustakaan dan Sains Informasi, Fakultas Teknologi Informasi, \\ Universitas YARSI, Jakarta
}

Korespondensi: ${ }^{1}$ fatehhibatulwafi@gmail.com, ${ }^{2}$ wardiyono@yarsi.ac.id

\begin{abstract}
ABSTRAK
Perpustakaan Hukum Daniel S. Lev memiliki banyak bahan pustaka berupa himpunan yurisprudensi, akan tetapi sistem temu kembali yang dimiliki masih dinilai belum efektif dan efisien. Beberapa sistem yang telah ada juga belum memenuhi kebutuhan penggunannya. Oleh karena itu, penelitian ini menawarkan solusi berupa pengembangan sistem temu kembali informasi yurisprudensi berbasis content management system (CMS). Penelitian ini bertujuan untuk: (1) menentukan kriteria sistem temu kembali informasi yurisprudensi terhadap masalah dari sistem sebelumnya dan kebutuhan pengguna saat ini; (2) mengembangkan sistem temu kembali informasi yurisprudensi berbasis cms di Perpustakaan Hukum Daniel S. Lev; dan (3) mengetahui hasil usability testing dari pengembangan sistem. Metode penelitian yang digunakan adalah studi kasus dengan pendekatan kualitatif untuk menganalisis kebutuhan sistem dan pendekatan kuantitatif untuk memperoleh data usability test. Teknik pengambilan sampel yang dilakukan adalah purposive sampling, maka diperoleh 3 sampel sebagai informasi dalam proses analisis kebutuhan sistem dan 8 sampel sebagai partisipan pada proses usability test. Hasil penelitian menghasilkankan: (1) diperolehnya latar belakang pengembangan sistem, analisis masalah sistem terdahulu dan berbagai spesifikasi kebutuhan sistem secara umum dan spesifik; (2) dibangunnya Direktori Yurisprudensi yang dapat mengkatalogisasi, menyimpan dan menemukan kembali data putusan yurisprudensi; (3) Direktori Yurisprudensi dinilai sebagai sistem yang sudah efektif dan efisien, sedangkan kepuasan pengguna terhadap sistem dinilai masih SEDANG.
\end{abstract}

Kata kunci: hokum, yurisprudensi, sistem temu kembali

\section{PENDAHULUAN}

Yurisprudensi merupakan suatu putusan hakim atas suatu perkara yang belum ada pengaturannya dalam undang-undang yang untuk selanjutnya menjadi pedoman bagi hakimhakim lainnya yang mengadili kasus-kasus serupa (Halim, 1988). Menurut Agustine (2018), di Indonesia belum terdapat kesepahaman mengenai pengertian yurisprudensi yang disetujui bersama, karena Indonesia terpengaruh oleh sistem hukum civil law yang memposisikan putusan yurisprudensi sebagai sumber hukum yang tidak mengikat oleh hakim. Jika ditinjau dari konsep fundamentalnya, yurisprudensi dapat diartikan sebagai ilmu, filosofi atau teori dari hukum (Stephenson, 2017). Kartini (2015) menjelaskan bahwa yurisprudensi merupakan keputusan pengadilan, khususnya keputusan yang dikeluarkan oleh pengadilan negara 
tertinggi, yaitu Mahkamah Agung. Berbagai keputusan-keputusan tersebut, menjadi dasar keputusan hakim lainnya untuk mengadili perkara serupa dan menjadi sumber hukum bagi pengadilan yang ada di bawahnya. Yurisprudensi juga merupakan salah satu sumber hukum yang penting dalam khazanah sumber-sumber formal hukum di dalam keluarga sistem hukum manapun (Shidarta, 2012). Koleksi ini sering dibutuhkan oleh para peneliti hukum yang sedang melakukan penelitian mengenai yurisprudensi. Sehingga, bagi Perpustakaan Hukum Daniel S. Lev, yang sebagian besar pengguna utamanya adalah mahasiswa, praktisi dan peneliti hukum, memiliki tugas untuk memudahkan setiap proses pencarian putusan yurisprudensi secara efektif dan efisien untuk penggunanya.

Sebelumnya, telah tersedia beberapa sistem temu kembali yurisprudensi yang khusus yang memuat putusan yurisprudensi tersebut, di antaranya adalah Direktori Putusan MA dan Indeks Hukum yang dimilki oleh Lembaga Kajian \& Advokasi Independesi Peradilan (LeIP). Akan tetapi, kedua sistem tersebut masih dinilai belum dapat memenuhi kebutuhan pengguna di Perpustakaan Hukum Daniel S. Lev, sebagaimana yang dijelaskan oleh Elnumeri pada diskusi tanggal 30 Juli 2018, beliau menjelaskan bahwa untuk meneliti dokumen mengenai yurisprudensi dan putusan penting, masih terdapat beberapa hal yang belum dapat dipenuhi oleh sistem temu kembali yurisprudensi Direktori Putusan MA, di antaranya seperti penelusuran berdasarkan klaster suatu istilah rujukan. Selain itu, terkait Indeks Putusan LeIP, hingga saat artikel ini ditulis, situs tersebut tidak dapat diakses atau dalam kata lain telah dinonaktifkan.

Berdasarkan dua masalah tersebut, Perpustakaan Hukum Daniel S. Lev memprakarsai pengembangan sebuah sistem temu kembali yurisprudensi sebagai solusi masalah. Akan tetapi, terdapat kendala karena sumber daya yang terbatas dalam hal dana ataupun tenaga yang ahli untuk mengembangkan sebuah sistem temu kembali yurisprudensi khusus untuk perpustakaan. Ghorecha \& Bhatt (2013) menulis CMS adalah alat yang berupa paket perangkat lunak yang memungkinkan penggunanya membangun sebuah website yang dapat digunakan untuk mengelola konten situs web dan menyimpan informasi di dalamnya. Martinez-Caro (2018) juga menjelaskan bahwa Web Content Management System (WCMS) merupakan platform perangkat lunak yang secara umum digunakan untuk kebutuhan website. Selain itu, WCMS mampu untuk membantu berbagai kebutuhan pengembangan web khususnya untuk pengembang web pemula atau para perusahan kecil. WCMS juga dapat diterapkan tanpa membutuhkan kemampuan pemograman web yang ahli.

Waworuntu dan Tanuar (2013) sudah berhasil membuat sebuah Document Management System (DMS) dengan memanfaatkan sebuah Content Management System 
Bibliotech : Jurnal Ilmu Perpustakaan dan Informasi, 4 (1) 2019

(CMS), Drupal versi 7. DMS sederhana ini berjalan dengan baik serta juga memenuhi berbagai kebutuhan utama sebuah DMS, mulai dari membuat data dokumen hingga menemukan kembali dokumen tersebut. Hal tersebut didukung dari CMS yang pada dasarnya sudah memiliki fitur untuk mengelola konten (content management) dan otentikasi pengguna (user authentication). Sehingga, dapat diasumsikan bahwa sebuah CMS dapat menjadi solusi alternatif untuk mengembangkan sebuah sistem sederhana yang mampu meminimalisir sumber daya.

Pada penelitian ini, peneiti menawarkan sebuah solusi untuk melakukan pengembangan yang sistem temu kembali informasi yurisprudensi berbasis CMS dengan menggunakan perangkat lunak Drupal sebagai solusi pengelolaan dan temu kembali putusan yurisprudensi yang dimiliki oleh Perpustakaan Hukum Daniel S. Lev. Solusi yang ditawarkan sekaligus menjawab tujuan penelitian berupa (1) penetapan kriteria sistem temu kembali informasi yurisprudensi terhadap masalah dari sistem sebelumnya serta kebutuhan pengguna saat ini; (2) membangun sistem temu kembali informasi yurisprudensi yang berbasis cms; dan (3) mengetahui sejauh mana usability test dari sistem yang dibangun.

\section{METODOLOGI}

Penelitian ini dilakukan dengan melakukan studi kasus dengan pendekatan kualitatif dan kuantitiatif. Pendektatan kualitatif digunakan untuk mengidentifikasi kebutuhkan sistem temu kembali informasi yang dibutuhkan oleh Daniel S. Lev. Sedangkan pendekatan kuantitatif digunakan untuk mengalisis data dari hasil usability test untuk mengetahui tingkat keberhasilan sistem yang dikembangkan.

Dalam pengembangan sistem, model prototyping atau pengembangan purwarupa akan digunakan dalam proses pengembangan. Model pengembangan sistem ini tidak membutuhkan kebutuhan statis atau tetap. Pada model ini, langkah awal yang lakukan adalah menciptakan sebuah desain kasar atau purwarupa, diuji coba dan dikembangkan ulang sebagaimana yang dibutuhkan hingga rancangan purwarupa dapat diterima dan memenuhi sasaran kebutuhan produk yang dikembangankan (Saxena \& Upadhyay, 2016).

Model purwarupa dikembangkan sesuai dengan kebutuhan klien dan tidak menetapkan kebutuhan sebelum proses perancangan, melainkan menetapkan kebutuhan ketika proses perancangan dan pengkodean. Tujuan dari model ini adalah untuk memungkinkan pengguna dari perangkat lunak untuk mengevaluasi desain produk dengan cara mencobanya langsung, sebelum produk benar-benar menjadi produk akhir, dan tidak menginterpretasikan dan 
mengevaluasi rancangan berdasarkan deskripsi (Gajalakshmi, 2016). Berikut adalah contoh ilustrasi dari alur model prototype:

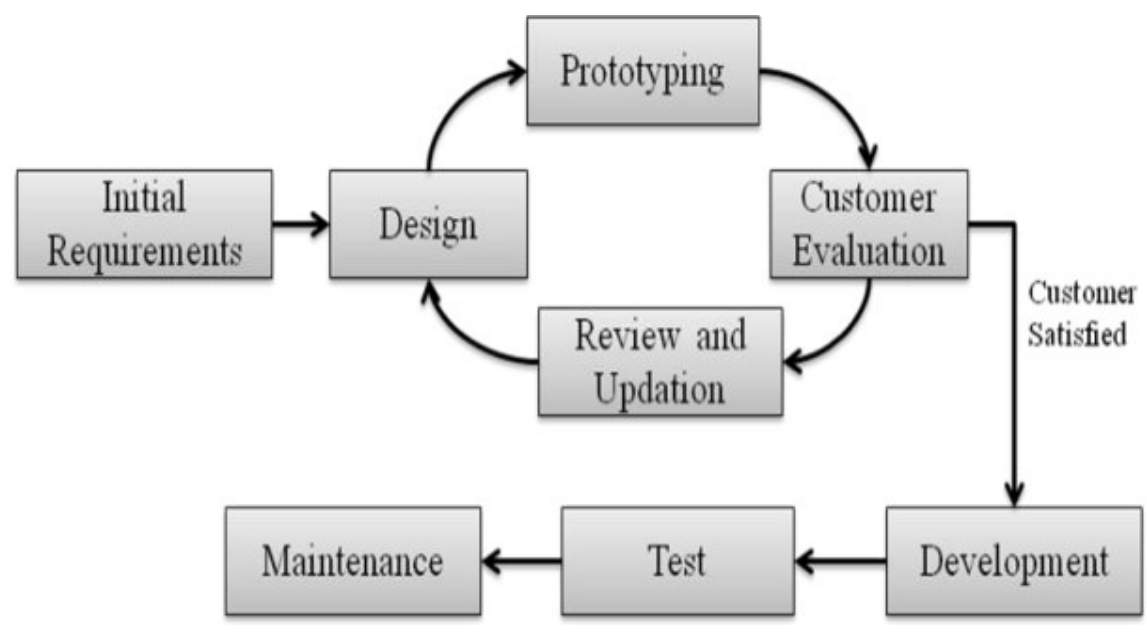

Gambar 1 Model Purwarupa

Sumber: Gajalakshmi (2016)

Populasi dari penelitian ini merupakan para calon pengguna sistem yang sedang dikembangkan, yang diantaranya adalah para pengguna sistem (mahasiswa, praktisi dan peneliti hukum). Teknik pengambilan sampel yang digunakan yaitu purposive sampling, dengan menyediakan kriteria dan pertimbangan khusus untuk menentukan sampel, dalam kata dilihat berdasarkan latar belakang profesi dan keahlian dari sampel. Sehingga, diperoleh 3 informan yang di antaranya:

- Praktisi hukum dari LeIP yang memiliki keahlian dalam bidang peradilan dan juga merupakan seorang koordinator dari sistem Indeks Hukum LeIP.

- Kepala Perpustakaan dari Perpustakaan Hukum Daniel S. Lev yang merupakan inisiator dari kegiatan pengembangan sistem dan juga seorang pustakawan yang menguasai bidang hukum.

- Pustakawan sistem dari Perpustakaan Hukum Daniel S. Lev yang merupakan calon administrator untuk sistem.

Sedangkan untuk, usability test menggunakan 8 orang partisipan yang terdiri atas 6 orang mahasiswa Sekolah Tinggi Hukum Indonesesia (STHI) Jentera sebagai pengguna potensial sistem dan 2 orang pustakawan dari Perpustakaan Hukum Daniel S. Lev sebagai pengelola sistem. Seluruh partisipan tersebut sebelumnya telah diseleksi untuk menyesuaikan dengan kriteria partisipan yang dibutuhkan untuk melakukan uji coba pada sistem. Selain itu, berdasarkan pertimbangan dari teori Tullis \& Albert (2013), dalam usability test direkomendasikan untuk menggunakan hanya 5-10 partisipan untuk menguji sistem yang memiliki ruang lingkup terbatas. 
Bibliotech : Jurnal Ilmu Perpustakaan dan Informasi, 4 (1) 2019

Menurut ISO 9241-210 (2010), usability (penggunaan) adalah tingkat sejauhmana suatu produk dapat digunakan oleh penggunanya untuk mencapai tujuan tertentu berdasarkan dari aspek efektifitas (effectiveness), efisiensi (effieciency) dan kepuasan (satisfaction) dalam konteks penggunaan yang telah ditentukan. Alat untuk mengukur usability testing disesuaikan dengan komponen usability yaitu efektivitas, efisiensi dan kepuasan pengguna. Aspek efektivitas dan efisiensi dapat diukur dengan menggunakan berbagai metrik dan penilaian observatif, sedangkan aspek kepuasan diukur menggunakan post task kuesioner. Untuk itu diperlukan skenario untuk memandu responden dalam menggunakan aplikasi. Skenario adalah kumpulan tugas yang harus dikerjakan responden pada saat menggunakan aplikasi (Nurhadryani et.al, 2013 )

Pengukuran penggunaan sistem (study usabaility) pada penelitian akan dilakukan dengan metode metrik. Metrik keberhasilan tugas atau task success adalah kategori metrik yang paling umum digunakan pada studi usability. Metrik ini hampir dapat diterapkan secara universal, karena dapat dihitung untuk berbagai macam hal yang sedang diuji, contohnya seperti dari situs web, selama pengguna memiliki tugas yang cukup jelas (Tullis \& Albert, 2013). Secara sederhana, tingkat keberhasilan tugas akan dihitung secara biner, yaitu berhasil dan tidak berhasil. Tullis \& Albert (2013) menjelaskan bahwa binary success digunakan ketika keberhasilan produk tergantung pada pengguna dalam menyelesaikan tugas atau serangkaian tugas. Selain itu, terdapat dua cara yang dapat digunakan untuk mengkalkulasikan task success:

- Melihat berdasarkan rata-rata tingkat kesuksesan dari setiap tugas yang dikerjakan oleh partisipan

- Melihat berdasarkan rata-rata tingkat kesuksesan dari setiap partisipan yang mengerjakan keseluruhan tugas

Metrik efesiensi untuk mempelajari kebiasaan pengguna pada penelitian digunakan lostness, sesuai Tullis \& Albert (2013). Sharon (2016) menjelaskan bahwa lostness adalah sebuah penilaian efisiensi terhadap penggunaan sebuah produk atau layanan digital, metrik tersebut mampu menilai seberapa tingkat "ketersesatan" sesorang ketika menggunakan sebuah produk. Kalkulasi pada metrik lostness membutuhkan tiga nilai (value) dan diterapkan dalam formula lostness yang di antaranya adalah (Tullis \& Albert, 2013):

$N$ : Jumlah halaman web berbeda yang dikunjungi partisipan ketika menyelesaikan tugas

$S$ : Jumlah total halaman web yang dikunjungi partisipan ketika menyelesaikan tugas, terhitung juga pengulangan halaman 
Bibliotech : Jurnal Ilmu Perpustakaan dan Informasi, 4 (1) 2019

$R$ : Jumlah minimum halaman web yang harus dikunjungi untuk menyelesaikan tugas (ditentukan oleh peneliti)

$$
\operatorname{Lostness}(\mathrm{L})=\sqrt{ }(N / S-1)^{2}+(R / N-1)^{2}
$$

Berdasarkan hasil dari formula tersebut, jika nilai lostness yang diperoleh lebih dari sama dengan $(>=)$ 0,4 maka dapat diasumsikan bahwa pengguna mengalami kendala dalam menyelesaikan tugas yang diberikan dan tidak dapat menyelesaikan tugas dengan efisien (Sharon, 2016).

System Usability Scale (SUS) yang dikembangankan oleh John Brooke pada 1986. SUS terdiri atas 10 pernyataan yang diantaranya terdapat masing-masing 5 pernyataan positif dan negatif terhadap sistem atau produk dan terdapat 5 poin penilaian untuk menyatakan kesetujuan pengguna (Tullis dan Albert, 2013). SUS dalam penelitian ini digunakan untuk mengukur apakah sistem yang dibangun dapat diterima oleh pengguna.

Menurut, Bangor et al dalam Brooke (2013) interpretasi terhadap nilai SUS dapat ditentukan berdasarkan:

- Jika nilai SUS 0-50, maka sistem dapat dikategorikan pada tingkat tidak dapat diterima (not acceptable)

- Jika nilai SUS 50-70, maka sistem dapat dikategorikan pada tingkat batas standar (marginal). Selain itu, pada marginal juga terdapat tingkatan yang lebih spesifik, yaitu low marginal (50-62) dan high marginal (63-70)

Jika nilai SUS 70-100, maka dinilai sistem dapat diterima (acceptable).

\section{HASIL DAN PEMBAHASAN}

\subsection{Identifikasi dan Analisis Kebutuhan}

Berdasarkan dari keseluruhan hasil wawancara yang dilakukan kepada Farli Elnumeri sebagai pustakawan, Arsil sebagai praktisi hukum dan Triawan Mardiasa sebagai administrator sistem, maka diperoleh beberapa data mengenai analisis masalah beserta solusi yang ditawarkan serta komponen kebutuhan sistem yang di antaranya adalah sebagai berikut:

Tabel 1 Masalah dan solusi yang ditawarkan

\begin{tabular}{|c|c|}
\hline Masalal & Solusi y \\
\hline $\begin{array}{l}\text { Sulit menemukan isu yang unik dari spesifik } \\
\text { pada sistem Direktori Putusan MA dan } \\
\text { Indeks Hukum }\end{array}$ & $\begin{array}{l}\text { Pembuatan ruas } \mathrm{k} \\
\text { kunci bebas yang ti } \\
\text { dan tidak baku }\end{array}$ \\
\hline
\end{tabular}




\begin{tabular}{|l|l|}
\hline $\begin{array}{l}\text { Putusan tidak diklasifikasi oleh ahli hukum } \\
\text { pada Direktori Putusan MA }\end{array}$ & $\begin{array}{l}\text { Data putusan yurisprudensi akan dimasukan } \\
\text { oleh pustakawan untuk menignkatkan } \\
\text { konsistensi dan juga diklasifikasi oleh } \\
\text { pustakawan yang memiliki keahlian di bidang } \\
\text { hukum }\end{array}$ \\
\hline $\begin{array}{l}\text { Pada Indeks Putusan LeIP, setiap putusan } \\
\text { akan dibaca satu per satu untuk mencari tahu } \\
\text { putusan yang memiliki isu penting atau } \\
\text { yurisprudensi }\end{array}$ & $\begin{array}{l}\text { Yurisprudensi akan diperoleh dari sumber } \\
\text { pustaka yang diterbitkan oleh MA dan oleh } \\
\text { para hakim }\end{array}$ \\
\hline $\begin{array}{l}\text { Indeks Putusan LeIP tidak dikelola oleh SDM } \\
\text { bidang teknologi informasi }\end{array}$ & $\begin{array}{l}\text { Sistem yang baru akan dikelola oleh } \\
\text { administrator sistem yang memiliki keahlian } \\
\text { di bidang teknologi informasi }\end{array}$ \\
\hline $\begin{array}{l}\text { Lampiran atau link yang ada pada Indeks } \\
\text { Putusan LeIP yang memuat file teks lengkap } \\
\text { putusan rusak karena bergantung pada server } \\
\text { lain }\end{array}$ & $\begin{array}{l}\text { Lampiran file akan langsung diunggah pada } \\
\text { server yang langsung dikelola oleh } \\
\text { Perpustakaan Hukum Daniel S. Lev }\end{array}$ \\
\hline
\end{tabular}

Merujuk Maurya, Pandey \& Maury (2013), temu kembali informasi merupakan proses mencari material yang tidak terstruktur dalam koleksi yang besar untuk memenuhi kebutuhan informasi. Sedangkan Manning, Raghavan \& Schutze (2008) menjelaskan bahwa temu kembali informasi merupakan proses untuk menemukan materi atau dokumen dari sifat yang tidak terstruktur (biasanya teks), yang sesuai dengan kebutuhan informasi dan diperoleh dalam kumpulan materi besar dan biasanya disimpan pada komputer. Melihat masalah dalam tabel 1, maka sistem yang ada bisa dianggap belum mampu mendukung proses temu kembali informasi yang dibutuhkan pengguna.

Jika temu kembali informasi dapat diartikan sebagai bentuk proses atau kegiatan, maka secara sederhana sistem temu kembali dapat diartikan sebagai media yang mendukung proses kegiatan tersebut maka sistem yang lama juga tidak sesuai dengan pemahanam tersebut. Beberapa fungsi dari Gondaliya \& Joshi (2017) dalam sistem temu kembali di antaranya adalah:

- Menyediakan informasi untuk pengguna dengan waktu dan usaha yang seminimalkan mungkin.

- Memfasilitasi informasi dan pengguna

- Menyediakan hasil pencarian yang tidak bersifat ambigu dengan cara menggunakan pengindeksan yang baik.

- Mudah digunakan oleh pengguna

Fungsi sistem temu kembali ini masih banyak yang belum dipenuhi sistem terdahulu.

Menurut Chowdhury (2010), sebuah sistem temu kembali memiliki 6 komponen subsistem, di antaranya adalah:

- Subsistem dokumen 
- Subsistem pengindeksan

- Subsistem kosakata

- Subsistem pencarian

- Tampilan sistem pengguna

- Subsistem kesesuaian

Merujuk pada masalah pada sistem-sistem terdahulu yang pernah digunakan perpustakaan Daniel S. Lev, kompenen-komponen subsistem ini perlu disempurnakan lebih jauh pada sistem yang akan dibangun.

Tabel 2 Komponen kebutuhan sistem

\begin{tabular}{|c|c|}
\hline Komponen & Kebutuhan dan Kriteria Utama Sistem \\
\hline Dokumen & $\begin{array}{l}\text { Sistem mampu untuk mengimplementasikan struktur data } \\
\text { berserta mendefinisikan tiap jenis data berdasarkan metadata } \\
\text { yurisprudensi yang telah tersedia. }\end{array}$ \\
\hline Pencarian & $\begin{array}{l}\text { Sistem mampu menyediakan pencarian sederhana dan } \\
\text { pencarian lanjutan. }\end{array}$ \\
\hline Pengindeksan & $\begin{array}{l}\text { Sistem tidak dibutuhkan untuk mengindeks putusan secara teks } \\
\text { lengkap. }\end{array}$ \\
\hline Taksonomi & $\begin{array}{l}\text { - Sistem memungkinkan pengelolaan tambah, edit dan } \\
\text { hapus) taksonomi dengan fleksibel } \\
\text { - Sistem memungkin untuk menghubungkan antar taksonomi } \\
\text { yang terdapat pada ruas yurisprudensi }\end{array}$ \\
\hline Pelaporan & $\begin{array}{l}\text { - Sistem mampu untuk membuat laporan rekapitulasi } \\
\text { mengenai total jumlah entri puturan secara keseluruhan dan } \\
\text { spesifik } \\
\text { Sistem mampu untuk menyimpan query pencarian atau kata } \\
\text { kunci pencarian yang dimasukan oleh pengguna Antar } \\
\text { Muka }\end{array}$ \\
\hline Sistem & Tampilan sederhana, elegan dan ringan sehingga mudah diakses \\
\hline Tingkatan Pengguna & $\begin{array}{l}\text { Dalam sistem terdapat tiga jenis pengguna yang di antaranya } \\
\text { terdiri dari: } \\
\text { - Administrator: memilik wewenang penuh atas sistem dan } \\
\text { memungkinkan untuk melakukan setiap kegiatan atau } \\
\text { tindakan pada sistem. } \\
\text { Kataloger: mengelola entri (menambahkan, menelusur, } \\
\text { menyunting dan menghapus data) serta mengelola } \\
\text { taksonomi. } \\
\text { Verifikator: hak akses untuk mengelola entri, mengevaluasi } \\
\text { data dan menerbitkan entri yang telah dimasukan oleh } \\
\text { kataloger. }\end{array}$ \\
\hline Lingkungan sistem & Sistem dimungkinkan dipasang secara online \\
\hline Format Lampiran & Sistem memungkinkan untuk melampirkan format PDF \\
\hline
\end{tabular}

\subsection{Hasil Pengembangan}

Sebagaimana yang telah dijelaskan sebelumnya, pada penelitian ini akan menggunakan pengembangan sistem temu kembali informasi dengan basis perangkat lunak 
Bibliotech : Jurnal Ilmu Perpustakaan dan Informasi, 4 (1) 2019

CMS Drupal. Pada tahap awal, penulis melakukan instalasi perangkat lunak tersebut pada lingkungan sistem yang telah sesuai dengan kriteriaminimum dari spesifikasi sistem yang dibutuhkan oleh Drupal.

Setelah melakukan instalasi Drupal, peneliti menambahkan berbagai modul pendukung yang sesuai dengan kebutuhan sistem. Beberapa modul yang dibutuhkan di antaranya adalah:

a) Date. Modul berfungsi mempermudah proses pendataan dan pengelolaan jenis data waktu atau tanggal yang dimiliki suatu konten. Dalam penelitian ini, modul Date dibutuhkan untuk definisikan data tanggal musyawarah dan tanggal dibacakan yang ada pada dokumen putusan yurisprudensi.

b) Views. Digunakan untuk mengelola tampilan konten, seperti memfilter konten yang ingin ditampilkan atau mensortir konten. Dalam penelitian ini, modul Views akan dimanfaatkan untuk membuat fitur pencarian lanjutan (advanced search) dan fitur penelusuran berdasarkan indeks

c) Administration Menu. Berfungsi untuk menyederhanakan tampilan bar kerja (toolbar) dari administrator, sehingga dapat mengefisiensikan proses kerja administrator, terutama apabila dituntut untuk melakukan perpindahan laman secara berkala.

d) Display Suite. Berfungsi untuk mengelola field atau ruas yang akan dimunculkan pada hasil pencarian atau dengan model teaser.

Setelah setiap modul telah disiapkan, peneliti mulai mengimplementasikan berbagai metadata yurisprudensi pada fitur Content Type dan taxonomy yang ada pada Drupal, sebagaimana gambar berikut: 


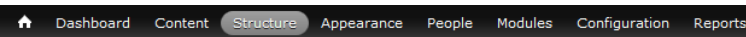

\begin{tabular}{|c|c|c|c|c|c|}
\hline LABEL & MACHINE NAME & FIELD TYPE & WIDGET & \multicolumn{2}{|c|}{ OPERATIONS } \\
\hline \& Judul Entri & title & Node module element & & & \\
\hline \# Sumber Pustaka & field_sumber_pustaka & Term reference & Autocomplete term widget (tagging) & edit & delete \\
\hline \& Nomor Putusan & field_nomor_putusan & Text & Text field & edit & delete \\
\hline 4. Perihal & field_perihal & Text & Text field & edit & delete \\
\hline \& Tingkat Proses & field_tingkat_proses & Term reference & Check boxes/radio buttons & edit & delete \\
\hline 4 Tahun Register & field_tahun_register & Term reference & Autocomplete term widget (tagging) & edit & delete \\
\hline \& Kamar & field_kamar & Term reference & Select list & edit & delete \\
\hline 4 Jenis Lembaga Peradilan & field_jenis_lembaga_peradilan & Term reference & Autocomplete term widget (tagging) & edit & delete \\
\hline 4. Para Pihak & field_para_pihak & Long text & Text area (multiple rows) & edit & delete \\
\hline 4. Tanggal Musyawarah & field_tanggal_musyawarah & Date & Pop-up calendar & edit & delete \\
\hline \& Tanggal Dibacakan & field_tanggal_dibicarakan & Date & Pop-up calendar & edit & delete \\
\hline \$ Dasar Putusan & field_dasar_putusan & Term reference & Autocomplete term widget (tagging) & edit & delete \\
\hline \& Amar & field_amar & Term reference & Select list & edit & delete \\
\hline \$ Catatan Amar & field_catatan_amar & Long text & Text area (multiple rows) & edit & delete \\
\hline 4 Bunyi Putusan & field_bunyi_putusan & Long text & Text area (multiple rows) & edit & delete \\
\hline
\end{tabular}

Gambar 2 Implementasi fitur content type

Setelah memastikan setiap pengelolaan data dapat berjalan dengan baik dengan fitur content type dan taxonomy, penulis mengimplementasikan rancangan peta sistem dan desain antar muka sistem yang dimodifikasi dengan menggunakan framework Bootstrap. Siklus pembuatan purwarupa ini dilakukan sebanak 2 (dua) kali. Maka hasil tampilan sistem temu kembali yurisprudensi adalah sebagai berikut:

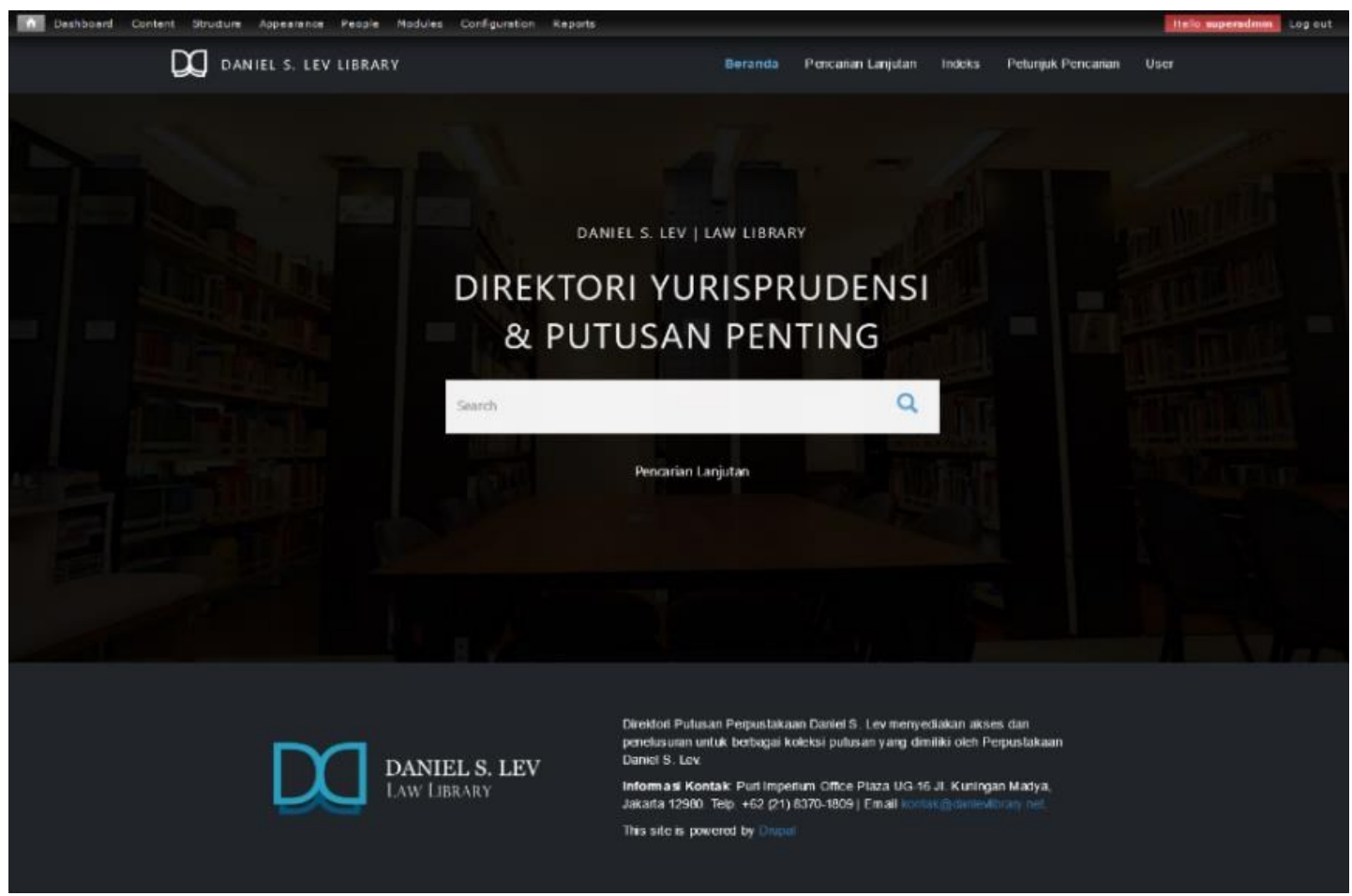

Gambar 3 Tampilan halaman depan Direktori Yurisprudensi 




Putusan MA No. 106 K/Kr/1973 Tahun 1973
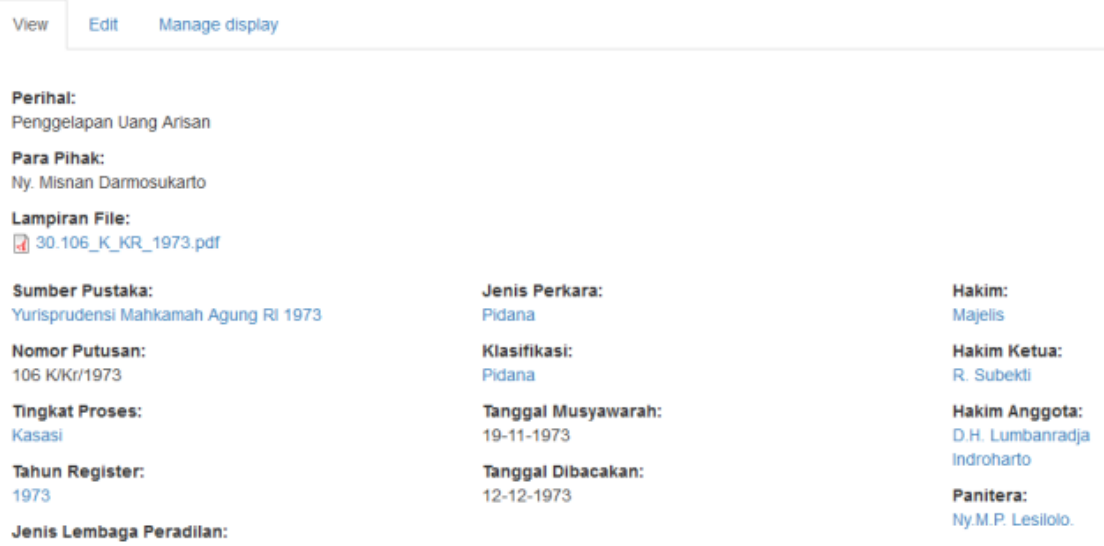

Gambar 4 Tampilan detail entri yurisprudensi

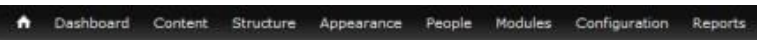

Pencarian Lanjutan

\begin{tabular}{l} 
Sumber Pustaka \\
\hline Uurisprudensi Mahkamah Agung Ril 1973 Kakim Ketua \\
\hline Tingkat Proses
\end{tabular}

Gambar 5 Fitur pencarian lanjutan

\subsection{Usability Test}

Penelitian usability testing ini tergolong sebagai summative usability (penilaian penggunaan yang bersifat sumatif) atau dapat diartikan sebagai penelitian untuk melakukan penilaian atau evaluasi pada pengguna terhadap suatu produk. Dalam kata lain, penelitian bertujuan untuk mengetahui apakah Direktori Yurisprudensi yang dikembangkan telah memenuhi tujuan penggunaannya dan bagaimana tingkat penggunaan keseluruhan dari sistem tersebut. Penulis menerapkan metode uji coba sistem dengan menggunakan skenario yang bersifat penyelesaian tugas, yang diberikan dan dilakukan oleh pada pengguna potensial dari 
sistem. Berbagai hasil dari uji coba tersebut pengguna akan menggunakan metrik UX untuk mengukur pengalaman (experience) pengguna terhadap sistem yang telah dikembangkan.

Dalam mengukur berbagai aspek, peneliti menggunakan metrik task success atau kesuksesan tugas sebagai aspek efektifitas, metrik efficiency sebagai penilaian aspek efisiensi dan selfreported metrics yaitu System Usability Scale (SUS) sebagai penilaian aspek penerimaan pengguna terhadap sistem yang sedang dibangun.

Penulis telah menyiapkan dua skenario yang diperuntukan bagi masing-masing jenis pengguna sistem, yaitu skenario pengguna sistem secara umum yaitu mahasiswa, praktisi dan peneliti) yang terdiri atas 7 buah tugas. Skenario kedua ditujukan kepada pengelola sistem (pustakawan) yang terdiri atas 10 buah tugas. Berbagai tugas tersebut telah dirancang dengan terlebih dahulu dengan dasar analisis kebutuhan sistem yang telah dijabarkan dibagian sebelumnya.

\section{a. Rekapitulasi Nilai Efektifitas dan Efisiensi pada Mahasiswa}

Pada Tabel 3 di bawah dapat disimpulkan bahwa jenis pengguna mahasiswa dapat menyelesaikan seluruh tugas yang diberikan secara efektif dan efisien. Dalam kata lain, mahasiswa dapat menyelesikan seluruh tugas yang diberikan dengan baik (efektif) dan melakukannya dengan proses cara yang tepat (efisien). Hal tersebut dapat terlihat dari nilai baik yang diperoleh pada rata-rata keberhasilan pengerjaan tugas dan rata-rata lostness (tingkat efisiensi).

Tabel 3 Rekapitulasi keberhasilan tugas \& nilai lostness Mahasiswa

\begin{tabular}{|c|l|c|c|}
\hline Kode & \multicolumn{1}{|c|}{ Deskripsi Tugas } & $\begin{array}{c}\text { Rata-rata } \\
\text { keberhasilan }\end{array}$ & $\begin{array}{c}\text { Rata-rata } \\
\text { lostness }\end{array}$ \\
\hline T1 & $\begin{array}{l}\text { Mencari sebuah putusan berdasarkan } \\
\text { nomor putusan dan unduh lampiran } \\
\text { putusan }\end{array}$ & $100 \%$ & 0,00 \\
\hline T2 & $\begin{array}{l}\text { Mencari sebuah putusan berdasarkan } \\
\text { perihal khusus dan mampu menentukan } \\
\text { jumlah putusan yang dicari }\end{array}$ & $100 \%$ & 0,14 \\
\hline T3 & $\begin{array}{l}\text { Mencari sebuah putusan berdasarkan nama } \\
\text { populer putusan }\end{array}$ & $100 \%$ & 0,06 \\
\hline T4 & $\begin{array}{l}\text { Mencari kumpulan putusan dengan dua } \\
\text { kriteria ruas menggunakan pencarian } \\
\text { lanjutan }\end{array}$ & $100 \%$ & 0,38 \\
\hline T5 & $\begin{array}{l}\text { Mencari kumpulan putusan berdasarkan } \\
\text { ruas nama hakim ketua }\end{array}$ & $100 \%$ & 0,10 \\
\hline T6 & $\begin{array}{l}\text { Mencari kumpulan putusan berdasarkan } \\
\text { dasar hukum tertentu dan menentukan } \\
\text { jumlahnya }\end{array}$ & $100 \%$ & 0,21 \\
\hline T7 & $\begin{array}{l}\text { Mencari seluruh daftar nama hakim } \\
\text { anggota yang ada pada sistem }\end{array}$ & $100 \%$ & 0,31 \\
\hline
\end{tabular}




\section{b. Rekapitulasi Nilai Efektifitas dan Efisiensi pada Pustakawan}

Pada Tabel 4 dapat disimpulkan bahwa jenis pengguna pustakawan (pengelola) dapat menyelesaikan tugas yang diberikan secara efektif dan efisien. Terdapat beberapa tugas yang tidak berhasil diselesaikan dan tidak dikerjakan dengan proses cara yang efisien. Dari 10 skenario tugas yang diberikan, terdapat 1 tugas (T10) yang tidak dapat efektif untuk diselesaikan dan 2 tugas (T7 dan T10) yang tidak dapat diselesaikan dengan efisien. Pada tugas T7, terlihat bahwa pustakawan dapat menyelesaikan tugas dengan efektif, akan tetapi proses cara yang dilakukan, dinilai masih tidak efektif. Berbeda dengan tugas T10 yang dinilai tidak berhasil diselesaikan (tidak efektif) dan proses pengerjaannya juga dinilai tidak efisien.

Tabel 4 Rekapitulasi keberhasilan tugas \& nilai lostness Pustakawan

\begin{tabular}{|c|l|c|c|}
\hline Kode & \multicolumn{1}{|c|}{ Deskripsi Tugas } & $\begin{array}{c}\text { Rata-rata } \\
\text { keberhasilan }\end{array}$ & $\begin{array}{c}\text { Rata-rata } \\
\text { lostness }\end{array}$ \\
\hline T1 & $\begin{array}{l}\text { Masuk atau login ke dalam sistem sebagai } \\
\text { pengelola }\end{array}$ & $100 \%$ & 0,00 \\
\hline T2 & $\begin{array}{c}\text { Mengubah mengubah kata sandi akun } \\
\text { T3 }\end{array}$ & $\begin{array}{l}\text { Menambahkan sebuah entri dokumen } \\
\text { yurisprudensi baru }\end{array}$ & $100 \%$ \\
\hline T4 & $\begin{array}{l}\text { Menghapus putusan yang perlu untuk } \\
\text { dihapus }\end{array}$ & $100 \%$ & 0,20 \\
\hline T5 & $\begin{array}{l}\text { Mencari data ruas pada suatu putusan yang } \\
\text { salah \& memperbaiki data tersebut }\end{array}$ & $100 \%$ & 0,00 \\
\hline T6 & $\begin{array}{l}\text { Mencari data taxonomy yang salah dan } \\
\text { menyunting taxonomy tersebut }\end{array}$ & $100 \%$ & 0,32 \\
\hline T7 & $\begin{array}{l}\text { Mencari daftar kata kunci atau frase yang } \\
\text { sering dicari oleh pengguna }\end{array}$ & $100 \%$ & 0,61 \\
\hline T8 & $\begin{array}{l}\text { Mencari kumpulan putusan berdasarkan } \\
\text { dasar hukum tertentu dan menentukan } \\
\text { jumlahnya }\end{array}$ & 1005 & 0,00 \\
\hline T9 & $\begin{array}{l}\text { Mencari seluruh daftar nama hakim } \\
\text { anggota yang ada pada sistem }\end{array}$ & $100 \%$ & 0,25 \\
\hline T10 & $\begin{array}{l}\text { Mencari jumlah keseluruhan putusan } \\
\text { yurisprudensi mengenai perdata dan pidana }\end{array}$ & $50 \%$ & 0,48 \\
\hline
\end{tabular}

\section{c. Rekapitulasi Keseluruhan Nilai Lostness (Efisiensi)}

Pada Tabel 5 di bawah dapat disimpulkan bahwa setiap jenis pengguna (mahasiswa dan pustakawan) dapat menyelesaikan seluruh tugas yang diberikan dengan proses cara efisien. Hal tersebut dapat disimpulkan dari nilai rata-rata lostness yang diperoleh kelompok pengguna mahasiswa dan pustakawan yang kurang dari 0,4. Selain itu, nilai rata-rata lostness keseluruhan juga mengindikasikan nilai yang efisien untuk meyelesaikan setiap tugas. 
Bibliotech : Jurnal Ilmu Perpustakaan dan Informasi, 4 (1) 2019

Tabel 5 Nilai Rata-rata Lostness dari Mahasiswa dan Pustakawan

\begin{tabular}{|c|c|c|}
\hline $\begin{array}{c}\text { Nilai rata-rata lostness } \\
\text { pada mahasiswa }\end{array}$ & $\begin{array}{c}\text { Nilai rata-rata lostness } \\
\text { pada pustakawan }\end{array}$ & $\begin{array}{c}\text { Nilai rata-rata lostness } \\
\text { keseluruhan }\end{array}$ \\
\hline 0,17 & 0,21 & 0,19 \\
\hline
\end{tabular}

\section{d. Rekapitulasi Keseluruhan Nilai SUS (Kepuasan)}

Pada Tabel 6, terlihat bahwa nilai rata-rata SUS yang diperoleh kelompok pengguna mahasiswa dapat dikategorikan sebagai nilai acceptable, dalam kata lain yaitu mahasiswa dapat menerima dan puas terhadap sistem Direktori Yurisprudensi. Sedangkan nilai ratarata SUS yang diperoleh kelompok pengguna pustakawan dapat dikategorikan sebagai nilai low marginal, dalam kata lain yaitu tingkat penerimaan atau kepuasan pustakawan terhadap sistem Direktori Yurisprudensi dinilai masih sedang atau biasa aja, tidak berada pada kategori dapat menerima dan tidak menerima. Berdasarkan nilai rata-rata SUS yang diperoleh mahasiswa dan pustakawan, maka nilai rata-rata SUS keseluruhan adalah high marginal atau batas tinggi mendekati penerima, dengan kata lain secara keseluruhan tingkat penerimaan atau kepuasan pengguan terhadap sistem Direktori Yurisprudensi masih biasa saja.

Tabel 6 Nilai Rata-rata SUS dari Mahasiswa dan Pustakawan

\begin{tabular}{|c|c|c|}
\hline $\begin{array}{c}\text { Nilai rata-rata SUS pada } \\
\text { mahasiswa }\end{array}$ & $\begin{array}{c}\text { Nilai rata-rata SUS pada } \\
\text { pustakawan }\end{array}$ & $\begin{array}{c}\text { Nilai rata-rata SUS } \\
\text { keseluruhan }\end{array}$ \\
\hline 72 & 53 & 76 \\
\hline
\end{tabular}

Sebagaimana yang terlihat pada Gambar 6, terlihat bahwa posisi nilai SUS Direktori Yurisprudensi dengan nilai rata-rata 67 atau high marginal yang merupakan batas antara dapat menerima dan tidak dapat menerima, dalam kata lainsedang atau biasa saja. Selain itu, terlihat bahwa posisi nilai SUS Direktori Yurisprudensi terletak diujung dari marginal high mendekati bagian acceptable. 


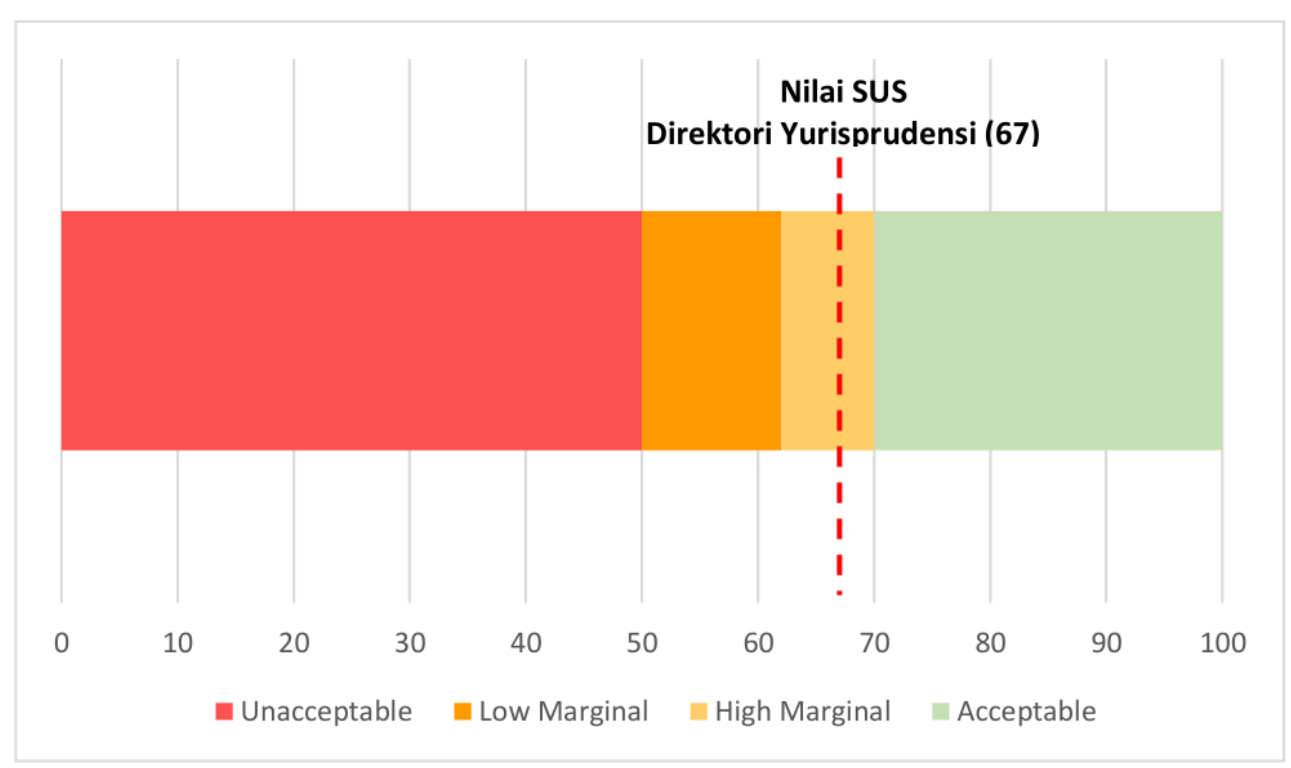

Gambar 6 Tingkat Nilai Rata-rata SUS Direktori Yurisrprudensi

\section{TINDAK LANJUT}

Pada proses analisis kebutuhan sistem, telah diperoleh latar belakang pengembangan sistem, analisis masalah dan proses kerja terhadap sistem terdahulu dan berbagai spesifikasi kebutuhan sistem secara umum dan spesifik. Berbagai kirteria sistem yang diusulkan oleh para informan adalah tersedianya sistem temu kembali informasi yang mampu untuk mengkatalogisasikan putusan yurisprudensi putusan berdasarkan metadata khusus yurisprudensi, menyimpan, menemukan kembali dan menampilkan data tersebut baik untuk pengguna maupun pengelola sistem.

Hasil dari produk pengembangan sistem informasi yurisprudensi Perpustakaan Hukum Daniel S. Lev diperoleh sebuah sistem temu kembali informasi dengan melakukan kustomisasi berbagai fitur dasar yang dimiliki oleh CMS Drupal. Fitur-fitur dasar ini dapat dimanfaatkan dengan optimal untuk memenuhi kriteria atau kebutuhan sistem yang diminta. Terdapat beberapa modul tambahan yang mampu meningkatkan fungsi dari sistem temu kembali informasi, seperti mendefinisikan data tanggal secara spesifik, mengelompokan ruasruas pengisian data dan menentukan representasi data yang akan ditampilkan

Hasil usability testing pada sistem Direktori Yurisprudensi, dapat disimpulkan bahwa sistem temu kembali informasi yurisprudensi dinilai sudah efektif dari konteks efektifitas dan efisien untuk penyelesaian berbagai transaksi tugas yang diberikan untuk setiap skenario. Pada aspek kepuasan atau tingkat pemanfaatan dari perspektif pengguna, sistem Direktori Yurisprudensi yang dibuat dapat dikategorikan sebagai marginal high atau batas tinggi antara kategori tidak dapat menerima dan dapat menerima, dalam kata lain cenderung dapat 
Bibliotech : Jurnal Ilmu Perpustakaan dan Informasi, 4 (1) 2019

diterima. Perhatian tambahan terhadap perbaikan sistem harus dilakukan khususnya terhadap nilai rata-rata SUS pada pustakawan, dalam hal ini sebagai administrator sistem. Penelitian lanjutan perlu dilakukan untuk mengidentifikasi lebih jauh kebutuhan dan harapan pustakawan terhadap sistem agar penerimaan mereka dapat lebih baik terhadap sistem yang telah dibangun.

\section{DAFTAR PUSTAKA}

Agustine, O.V. (2018). Keberlakuan Yurisprudensi pada Kewenangan Pengujian UndangUndang dalam Putusan Mahkamah Konstitusi. Jurnal Konstitusi,15(3), pp. 642-665.

Brooke, J. (2013). SUS: a Retrospective. Journal of Usability Studies, 7(2), pp. 29-40.

Chowdhury, G. (2010). Introduction to Modern Information Retrieval, 3 rd ed, London: Facet Publishing.

Gajalakshmi, P. (2016), Software Development Lifecycle Model (Sdlc) Incorporated With Release Management, International Research Journal of Engineering and Technology, 3(4), pp. 1536-1543.

Ghorecha, V. \& Bhatt, C. (2013). A guide for Selecting Content Management System for Web Application Development, International Journal of Advance Research in Computer Science and Management Studies, 1(3), pp.13-18.

Gondaliya, T. \& Joshi, H. (2017) Review, Journey of Information Retrieval to Information Retrieval Tools - IR\&IRT, dalam International INFLIBNET Centre, pp. 158-169.

Halim, A. (1988) Hukum Pidana Dalam Tanya Jawab, Jakarta: Ghalia Indonesia.

International Organization of Standardization. (1 October 2018). ISO 9241-210:2010 :

Ergonomics of human-system interaction - Part 210: Human-centred design for interactive systems,https://www.iso.org/obp/ui/\#iso:std:iso:9241:-210:ed-1:v1:en

Kartini (2015). Pemberdayaan Yurisprudensi sebagai Sumber Hukum Islam. Jurnal Al- 'Adl, 8(1), pp. 141-155.

Manning, C., Raghavan, P. \& Schutze, H. (2008). Introduction to Information Retrieval. New York: Cambridge University Press.

Martinez-Caro, J. et al. (2018). A comparative study of web content management systems. Information, 9(2), pp. 1-15.

Maurya, V., Pandey, P. \& Maurya, LS. (2013). Effective Information Retrieval System, International Journal of Emerging Technology and Advanced Engineering, 3(4), pp. 787-792. 
Bibliotech : Jurnal Ilmu Perpustakaan dan Informasi, 4 (1) 2019

Saxena, A. \& Upadhyay, P. (2016). Waterfall vs . Prototype : Comparative Study of SDLC, Imperial Journal of Interdisciplinary Research, 22(6), pp. 1012-1015.

Sharon, T. (2016). Validating Product through Lean User Research, Brooklyn: Rosenfeld Media.

Shidarta. (2012). Mencari Jarum 'Kaidah' di Tumpukan Jerami 'Yurisprudensi', Jurnal Yudisial 5(3), pp.331-343.

Stephenson, P.R. (2017). Defining a Cyber Jurisprudence, dalam Annual ADFSL Conference on Digital Forensics, Security and Law, pp. 123-127.

Tullis, T. \& Albert, B. (2008). Measuring the user experience: Collecting, Analyzing and Presenting Usability Metrics, 2 nd ed.,Waltham: Elsevier.

Waworuntu, A. \& Tanuar, E. (2013). Document Management System menggunakan OpenSource CMS, Drupal. Jurnal Teknologi Informatika, 5(2), pp. 19-31. 
Bibliotech : Jurnal Ilmu Perpustakaan dan Informasi, 4 (1) 2019 